IZA DP No. 6658

Is the Erosion Thesis Overblown? Evidence from the Orientation of Uncovered Employers

John T. Addison

Paulino Teixeira

Katalin Evers

Lutz Bellmann

June 2012 


\title{
Is the Erosion Thesis Overblown? Evidence from the Orientation of Uncovered Employers
}

\author{
John T. Addison \\ University of South Carolina and IZA \\ Paulino Teixeira \\ University of Coimbra and IZA \\ Katalin Evers \\ Institute for Employment Research (IAB) \\ Lutz Bellmann \\ University of Erlangen-Nuremberg, IAB and IZA \\ Discussion Paper No. 6658 \\ June 2012 \\ IZA \\ P.O. Box 7240 \\ 53072 Bonn \\ Germany \\ Phone: +49-228-3894-0 \\ Fax: +49-228-3894-180 \\ E-mail: iza@iza.org
}

\begin{abstract}
Any opinions expressed here are those of the author(s) and not those of IZA. Research published in this series may include views on policy, but the institute itself takes no institutional policy positions.

The Institute for the Study of Labor (IZA) in Bonn is a local and virtual international research center and a place of communication between science, politics and business. IZA is an independent nonprofit organization supported by Deutsche Post Foundation. The center is associated with the University of Bonn and offers a stimulating research environment through its international network, workshops and conferences, data service, project support, research visits and doctoral program. IZA engages in (i) original and internationally competitive research in all fields of labor economics, (ii) development of policy concepts, and (iii) dissemination of research results and concepts to the interested public.
\end{abstract}

IZA Discussion Papers often represent preliminary work and are circulated to encourage discussion. Citation of such a paper should account for its provisional character. A revised version may be available directly from the author. 


\section{ABSTRACT \\ Is the Erosion Thesis Overblown? Evidence from the Orientation of Uncovered Employers}

It is sometimes claimed that the coverage of collective bargaining in Germany is considerably understated because of orientation, a process whereby uncovered firms profess to shadow the wages set under sectoral bargaining. Yet importantly, at a time when collective bargaining proper has been in retreat, little is known of corresponding trends in the frequency of indirect coverage, still less of the degree to which wages are aligned in practice. Using nationally representative data for 2000-2010, this paper charts the extent of orientation in the uncovered sector, and tracks average wages across bargaining regimes as well as changes in wages from switches in regime. It is reported that orientation is growing with the decline in sectoral bargaining and that orienting firms do pay higher wages than their counterparts in the collective bargaining free zone. Yet in neither case - frequency nor remuneration - is the degree of 'compensation' recorded other than partial.

JEL Classification: J31, J5

Keywords: orientation, erosion of collective bargaining, uncovered sector, sectoral bargaining, wages, regime shifts

Corresponding author:

John T. Addison

Department of Economics

Moore School of Business

University of South Carolina

1705 College Street

Columbia, SC 29208

USA

Email: ecceaddi@moore.sc.edu 
In Germany since unification, we witness a process of erosion rather than breakdown .... Bargaining coverage in the private sector was more or less stable - around 70 percent or more - in West Germany before unification and is currently estimated at 59 percent in western and 36 percent in eastern Germany. However, half of these nonorganized firms nonetheless orient themselves toward the sector agreements and follow its basic features on pay and working time. This pushes the German coverage rate up by 10-15 percentage points'. (Visser, 2006: 494.)

'Since the mid-1990s, the German system of collective bargaining has been faced by a process of creeping erosion. While bargaining coverage has shown a steady decline, a far-reaching decentralization has increasingly undermined the system of multi-employer bargaining'. (Bispinck, Dribbusch, and Schulten, 2010:2.)

\section{Introduction}

It is now accepted that the traditional bargaining system in Germany based on sectoral bargaining, and underwritten by a framework of workplace codetermination, has been subject to erosion in recent years (see, for example, Kohaut and Schnabel, 2003a,b; Kohaut and Ellguth, 2008; and Ellguth and Kohaut, 2010). Not only has the institutional base been shrinking since the 1990 s but there has also been an increasing tendency toward decentralization (e.g. Ochel, 2005). There is disputation as to the teleological outcome of this process. Some observers argue that a system once renowned for its robustness and potential for promoting social cohesion is now actually destabilizing (see, in particular, Hassel, 1999, 2002; Bispinck et al., 2010). Others, while accepting that changes in the status quo ante are more than a veil (behind which the operation of traditional regional and industry bargaining structures is unchanged) nevertheless contend that existing structures have permitted transformation without disruption (Frege, 2003; Thelen and van Wijnbergen, 2003; Streeck and Thelen, 2004).

Unfortunately, comprehensive analysis of the changing architecture of German industrial relations has often lagged the evolving debate. ${ }^{1}$ This is in part inevitable since examination of the decentralization thesis requires individual case studies and detailed evaluation of internal changes in the bargaining system (e.g. Doellgast and Greer, 2007; Massa-Wirth and Niechoj, 2004; Haipeter and Lehndorff, 2009). But a lack of factual information has also served to impair the debate on the erosion of the system. One obvious case in point has been the comparative lack of parallel data on works council 
coverage. If works councils are in decline, then the ingredients for organized or stabilizing decentralization are simply missing. Another example is the tendency - until recently at least - to neglect the role of political support, a negative example of which is the atrophy of the extension mechanism whereby the terms of sectoral agreements are extended by the federal labor ministry to all companies within a specific sector (see Bispinck et al., 2010: 5-6). More generally of course, as Hassel (2002: 315) has pointed out, were it not for active political support - in the form of a consensus to maintain a highly regulated and centralized system of industrial relations - the process of institutional erosion would have been even more rapid than has been observed. The extension example given above touches more on the issue of the external erosion of the system. In this area, too, up-to-date factual information on the extent of sectoral and firm-level bargaining and the bargaining free zone has often been lacking (see Addison et al., 2011).

The present paper squarely addresses the issue of external erosion. Its goal is not to provide chapter and verse on the full range of institutional changes with a direct bearing on the changing architecture of German industrial relations. Rather, its concern is with the evolution of a single institution factor: orientation. Orientation refers to the well-known but inherently ambiguous practice of a subset of firms within the collective bargaining free zone claiming to orient themselves or otherwise pay heed to the terms and conditions established by the relevant sectoral agreement. We seek to determine whether this practice qualifies the (external) erosion thesis. To this end, we examine not only changes in the proportion of firms professing to orient themselves to traditional agreements but also the (average) wages paid under orientation versus no orientation.

To anticipate our findings, we report that there has been a growth in orientation at the very time that sectoral bargaining proper has declined - and seemingly continues to decline. We also report higher average wages in cross section among the firmament of orienting firms vis-à-vis their nonorienting counterparts in the collective bargaining free zone. And although wage levels under 
orientation are distinctly lower than those determined under collective bargaining, we report that wage changes tend to be more closely aligned. For those firms leaving sectoral bargaining, wage increases are greater among those that go on to orient themselves toward sectoral agreements. For joiners, on the other hand, the expected result of convergence is muddied by the seemingly more heterogeneous nature of the sample of joiners.

\section{Data}

Our data are extracted from the IAB Establishment Panel, or Betriebspanel. This is a nationally representative panel of establishments based on a stratified random sample of the population of all establishments with at least one employee covered by social insurance (see Fischer et al., 2009). Currently, the stratification currently has a basis in 19 industries and 10 employee size classes. As of 2010, the Panel encompassed more than 16,000 establishments.

Respondents to the Panel questionnaire are asked questions on a wide set of issues, including the type of collective bargaining coverage, the number of employees in employment, and the wage bill. The questionnaire distinguishes between two types of collective bargaining: sectoral agreements, the dominant form of collective agreement negotiated at sectoral level by the regional associations of employers and trade unions (so-called Flächentarifvertrag or Branchentarifvertrag), and separate agreements based on negotiations between the firm and a union(s) (Firmentarifvertag). Note that the identity of the sectoral agreement is not disclosed so that we cannot link firms to a specific tariff. In addition, plants are asked to state if they do not practice collective bargaining, and since 1999 such establishments that individually bargain with their employees have been asked whether or not they nonetheless orient themselves to a sectoral agreement. ${ }^{2}$

Establishments are also asked as of June 30 in each year to state the total sum of gross wages and salaries for that month (excluding the employer share of social security payments as well as holiday 
pay). Separate questions on the total number of workers employed at this qualifying date (net of trainees, temporary agency workers, and certain other residual categories) were used in conjunction with the share of part-time workers to compute the average bill per full-time equivalent employee. This is our raw measure of the establishment average wage. Real wages (i.e. year 2000 wages) are used throughout, the inverse of the consumer price index being used as a deflator.

Our selected observation window is 2000-2010, the beginning period being determined in part by changes in industrial classification that we wish to avoid having to deal with. However, a further change in industrial classification occurred in 2009 and this will affect our sectoral analysis, even if our selection of five groups was designed to minimize the problem. This should be borne in mind in interpreting the last two years of data in the disaggregated analysis. More generally, the longitudinal nature of the Establishment Panel allows us to track transitions into and out of collective agreements, which is the final component of our discussion of the wage implications of orientation and further detail on which is provided below. Note, too, that we will also look at a particular set of establishments that are observed in every single wave - the category of permanent stayers - and considered alongside unrestricted cross sections of data.

Our focus is upon establishments from the private sector of the economy (excluding agriculture), with at least five employees. More precisely, we exclude all establishments that over the relevant observation window always had less than five employees. This filter reflects our concern that the excluded plants are more prone to measurement error with respect to both collective bargaining status and wages. In similar vein, we all also excised all those establishments whose reported annual changes in the wage bill per employee were unrealistic. (Here exceeding $100 \%$ or more.)

\section{Findings}

\section{The Extent of Orientation}


We examine the extent of orientation first at the most aggregate level before turning to region, specific sector, and firm size. In each case, we examine collective bargaining coverage and absence of coverage by establishment share and by proportion of workers affected. Tables 1 and 2 set the scene. Table 1 confirms the erosion of sectoral bargaining widely noted in the literature (see, in particular, Addison et al., 2011). Moreover, the seeming pause in decline for 2009 noted by some other observers does not appear to have persisted beyond that year (see also Ellguth/ Kohaut, 2011). We observe a 23.5 percent fall in the number of establishments covered by sectoral bargaining over the eleven-year sample period, and even the suggestion of a decline in firm-level bargaining at end period. But to be sure the share of orienting plants has increased by 21.9 percent - from 24.2 percent to 29.5 percent of all plants. That said, there has been a higher growth (30.4 percent) in the share of non-orienting plants over the period. In short, even if we were uncritically to add the share of orienting plants to those formally practicing sectoral bargaining, the total would register a decline from 73.5 percent in 2000 to 67.2 percent in 2010 .

Table 2 examines collective bargaining coverage by employees. Greater shares of employees than establishments are covered by sectoral bargaining given the higher incidence of collective bargaining in larger firms - and conversely for the bargaining free zone. But the trends earlier found for establishment coverage apply equally to employee coverage: sectoral bargaining is and continues to be in decline while orientation is increasing. Of course, the proportion of workers in firms practicing individual bargaining is also increasing but as of end of period such individuals are outnumbered by their counterparts employed in orienting firms.

(Tables 1 and 2 near here)

Tables 3 and 4 disaggregate by broad region. Collective bargaining coverage by establishment shows the familiar pattern: sectoral bargaining is markedly lower in eastern than in western Germany (and the bargaining free sector correspondingly higher), while firm-level bargaining is higher but still of somewhat low frequency. Beginning with the coverage by establishment data in Table 3, we see that the 
share of orienting plants is higher in eastern Germany at around 33 percent but displays no discernible trend over the sample, whereas in western Germany it has grown by 30.6 percent of all establishments. While the share of non-orienting plants has also risen in both parts of Germany, they do not outnumber orienting plants in western Germany. Sectoral bargaining has declined by $27.6(23.3)$ percent in eastern (western) Germany. If we simply add orienting firms to those engaging in sectoral bargaining, however, the rates of decline are just 11.4 percent in eastern Germany and 8.1 percent in western Germany.

Much the same patterns emerge when we consider coverage rates by numbers of employees affected. Thus, sectoral bargaining has declined in both eastern and western Germany (by 15.5 percent and 23.3 percent, respectively) and the bargaining free sector is again higher in eastern than western Germany (57.3 percent versus 39.7 percent of all employees). Adding the numbers of employees covered by orientation to those covered by sectoral bargaining, however, again produces smaller declines in direct and indirect sectoral bargaining of 5.8 percent in western Germany and 11.8 percent in eastern Germany.

(Tables 3 and 4 near here)

We next consider coverage rates in specific sectors of the economy. Unfortunately, there occurred changes in industrial classification in 2009 such that the same establishment can populate two different sectors over the full sample period, although they do not eliminate them. The five sectors shown in Tables 5 and 6 were designed to minimize such problems. (Full definition of the sectors is provided in the Appendix.) The coverage data by plant in Table 5 generally point to a decline in sectoral bargaining (other than in Business Services) which is more pronounced in some sectors (primarily Trade, Transport, and Finance and Manufacturing) than others (most notably Construction). By the same token orientation seems to have been more compensatory where sectoral bargaining has declined most. For example in Trade, Transport, and Finance where sectoral bargaining declined by 36.3 percent, orientation grew by 48.7 percent such that the two taken together fell by just 11.0 percent. In 
Manufacturing the respective changes were 26.5 percent, 12.3 percent, and 10.6 percent. And in Other Services the sectoral bargaining fell by 15.6 percent, orientation grew by 40.0 percent, indicating an increase in joint coverage of 2.9 percent.

(Tables 5 and 6 near here)

A not dissimilar picture is found when we examine branch coverage by the number of employees affected in Table 6. Business Services is again an exception by reason of its growth in sectoral bargaining coverage and decline in orientation - and even non-orientation.

Finally, we consider changes in coverage by plant size in Tables 7 and 8. From Table 7 we see that sectoral bargaining coverage is monotonically increasing in firm size on the share of establishments measure but has declined within all three size class intervals. The decline has been greatest in smaller plants with between 5 and 49 employees (at -25.1 percent). It has been just under one-half that among medium-sized (50-249 employees) and the largest plants (250 or more employees). In all cases, however, orientation has grown and this growth is increasing in establishment size. The net effect is that, once we add formal and indirect sectoral bargaining, the reductions in coverage decline by 9.3 percent in the smallest plants, by 1.8 percent in intermediate size plants, and by 3.3 percent in the largest plants. Here, then, we see rather clear indication of heightened orientation compensating for the decline in sectoral bargaining.

Turning to coverage by the number of employees affected, the data in Table 8 very closely resemble those in Table 7. If there is a difference, it concerns the largest firms where the growth in orientation is lower than on the establishment measure.

(Tables 7 and 8 near here)

\section{Wages under orientation}

We have seen that there has been a growth in the extent of orientation through time among firms practicing individual bargaining. But it remains the case that this growth has typically only partially 
compensated for the decline in sectoral bargaining proper, whether measured in terms of plants or numbers of employees affected. Further, recalling Guertzgen's (2006: 9-10) reservations as to the limited informational content of the orientation question in the IAB Panel, is it true that wages in firms claiming to pay heed to the relevant sectoral agreements are in fact higher than in the rest of the collective bargaining free sector? To help answer this latter question, we will examine wage developments by type of collective agreement and by absence of collective agreement. (As in the previous descriptive analysis firm-level bargaining is addressed only en passant.) We first consider the course of average wages (viz. the monthly real wage bill divided by the number of full-time equivalent workers; see section II) in each year of the sample period, both for the full cross section and for the subsample of permanent stayers. We then turn to examine changes in average wages over three consecutive years for those firms abandoning sectoral agreements and for those firms joining sectoral agreements. We repeat the exercise, this time using four consecutive years of data where changes in status are observed; that is, we allow for wage changes in the year preceding the switch in status as well as in the subsequent two years.

\section{(Tables 9 and 10 near here)}

Mean unweighted real wages for our eleven annual cross sections of data are provided in Table 9. It can be seen that real wages are unequivocally higher under collective bargaining than in its absence and that, with the exception of a single year, plant-level bargaining is associated with the highest wages of all. In 2000 the average wage in uncovered non-orienting plants was $87.4 \%$ of that paid under the generality of sectoral agreements, and by 2010 this ratio was practically unchanged at just over $87 \%$. Corresponding values for orienting establishments were $88.7 \%$ and $89.5 \%$. At this level of aggregation, the seemingly most important development was the change in the relation between firm and sectoral bargaining: average wages under firm-level bargaining rose from $100.5 \%$ to $106.5 \%$ of those paid under sectoral agreements over the sample period. 
Turning to the sample of permanent stayers, much the same patterns are evident in the data. Thus, average real wages tend to be higher under firm-level agreements, especially in the second half of the period. In turn, wages in orienting firms now clearly exceed those in non-orienting firms: in 2000 the ratio of average wages in orienting (non-orienting) firms to those in plants observing sectoral agreements was 88.7 percent ( 87.4 percent). By 2010 the former ratio had risen to 89.5 percent and the latter was little changed at 87.1 percent. $^{3}$

Another way of looking at the evidence is to examine changes in wages attendant upon firms joining or leaving sectoral agreements according to their initial/subsequent status as either uncovered orienting or non-orienting firms - a type of unconditional difference-in-differences approach. Given the above evidence, we know that 'orientation' merits its informal tag and certainly appears not equivalent to having wages set at the agreed collective agreement level. Subject to the caveat that we cannot link firms to specific sectoral agreements, our goal is to determine what switchers would have gain in wage increases had they not switch.

Let us firstly briefly elaborate on our empirical strategy. The first step consists of selecting establishments that are observed for three consecutive years over our sample period, 2000-2010. Next, we divide this subsample into those establishments that are covered by a sectoral agreement over the entire sequence (call them 'sectoral agreement stayers'); those who leave after the first year but who orient toward a sectoral agreement in the following two years ('orienting leavers'), and those who seemingly abandon for good any contact with collective bargaining ('non-orienting leavers'). We can also represent these three groups by the specific sequences (scb-scb-scb), (scb-orient-orient), and (scbnoorient-nooreint), respectively. Similarly, for sectoral agreement joiners, we have the sequences (orient-scb-scb) and (noorient-scb-scb), where the former denotes the transition from orientation to sectoral agreement and the latter the transition from non-orientation to sectoral agreement coverage. ${ }^{4}$ 
The next step is to compute and compare the wage growth profiles of the all groups over the full three-year sequence, $t-1, t$, and $t+1$. Observe that we decided to look at three consecutive years of data, rather than just two, to reflect the possibility that the effect of leaving/joining may not be immediate. We shall also present results from deploying four consecutive years of data, comprising two years before leaving/joining and two years with the new collective bargaining status. In this case, we have, in years $t-2, t-1, t$, and $t+1$, the sequences (scb-scb-scb-scb), (scb-scb-orient-orient), (scb-scb-noorientnoorient), (noorient-noorient-scb-scb), and (orient-orient-scb-scb). By observing two consecutive years before switching, we hope to be able to detect any distinctive pre-exit collective agreement behavior.

To complement the analysis on the impact of collective agreement transitions on establishment wage change, we will also comment on absolute wage levels observed in year $t-1$ for all selected groups vis-à-vis the wage data earlier observed in cross-section. The goal here is to detect the extent to which, for example, the initial wage level of sectoral agreement stayers differs from the wage observed for the entire group of establishments covered by a sectoral agreement. Similarly, for sectoral agreement leavers and joiners, the main issue would be whether the wage level of a sectoral agreement leaver/joiner in the year before leaving/joining is close enough to the average wage of the corresponding group. Put differently, we want to check whether the selected group of movers and stayers reflect the wage structure observed in Table 9.

\section{(Table 11 near here)}

Table 11 provides evidence on beginning-period wages for the different groups of stayers and movers. Here the relevant comparison is with Table 9 (or Table 10). Observe firstly that wages among sectoral agreement stayers in first column and first row of Table 11 are slightly above the average wage level that can be calculated from Table 9 (i.e. $€ 2,179.8$ in column 1 and $€ 2,206.1$ in column 2 as compared with an average of $€ 2,115.2$ across all cross-section in Table 9). Next, sectoral agreement leavers seem to have in the base year lower wages than the average sectoral agreement affiliate. Joiners 
that previously did not practice orientation had lower wages than their counterparts that did orientate. Interestingly, the wage structure given in the second column - the 4-year case - closely accords with the first column. Hierarchies are preserved. Orienting firms have higher base wages than non-orienting firms irrespective of whether they are stayers or movers.

(Figure 1 near here)

Figure 1 depicts wage growth for leavers versus stayers in the three-period sequence. Stayers apparently earn higher wage increases over the period than do leavers. This is not an unexpected result given our earlier results to the effect that it is better to be covered than not covered, subject to the caveat that we are observing an average contract, not the specific contract being followed/abandoned. Despite low real wage growth over our sample period, the differences between groups are transparent; in particular, those leavers that orient do stay closer to the growth pattern of stayers than those who leave and do not orient.

(Figure 2 near here)

Figure 2 presents the results for sectoral agreement followers and joiners, again for the threeyear sequence. Joining a collective agreement seems to pay off, with a big jump in wage growth rate in the first year after joining followed by convergence. In other words, by year $t+1$ all groups will have had their wages increased by approximately the same proportion. Note that the original wage levels of the joining groups in Figure 2 are much lower than the wages of the leavers in Figure 1 (see Table 11).

(Figures 3 and 4 near here)

Figures 3 and 4 present the results for leavers and joiners for the four-year sequence, where we are also examining pre-transition wage growth. Beginning with Figure 3, the gains from being covered throughout are seemingly transparent. Stayers record a cumulative wage growth of approximately 8 percent by the fourth year, which is conspicuously higher than for leavers, especially for non-orienting leavers. The wage pattern of non-orienting leavers in the year preceding switching might suggest that 
firms sought to leave sectoral agreements as a means of cost containment. But no such argument can be deployed in the case of orienting leavers whose pre-transition wage growth was negligible and well below the average observed for all sectoral agreements. After leaving their sectoral agreements, their wage increases do however seem to track the whole-sector contract average more closely than before.

Turning to joiners, Figure 4 suggests that their lower initial wage increases are followed by a comparatively rapid advance in wages after joining, especially in the case of the non-orienters. We can only speculate about patterns of behavior in this group. Arguably, non-orienters had higher wage growth than orienteers because they had more to make up. Orienters, on the other hand, may only have loosely tracked the relevant sectoral agreement prior to their joining it. Their subsequent increases while lower than those of non-orienting joiners might well represent no less exact following of the terms of the relevant sectoral agreement. Note here that both groups of joiners have the lowest initial real wage levels of any group of movers. Specifically, the initial wages of orienting/non-orienting joiners were just $€ 1,765.6 / € 1,859.1$ (see Table 11).

\section{Conclusions}

The ambiguity concerning orientation, the shadowing of sectoral agreements by uncovered firms formally practicing individual bargaining alone, is two-fold. First, and least opaque, is the question of its frequency. That is, the IAB Establishment Panel directly inquires of firm respondents in the collective bargaining free zone whether or not they informally follow the terms of an industry-wide agreement. Despite this data availability, however, scant attention is accorded it in the wage literature and unaccountably still less in the much larger body of empirical work devoted to the erosion thesis. In the present paper, we have sought to remedy this factual information deficit by providing several time series on the extent of orientation. Second, but much more difficult, is the extent to which firms professing to informally follow sectoral agreements do so in practice. This is akin to the issue of pattern 
bargaining, to resurrect reference to an Anglo Saxon literature. Full investigation of this issue would involve examination of detailed bargaining constellations (see Addison and Burton, 1977). Our approach here can only be indirect as we lack information on the actual sectoral agreements in play. Instead, we compare average wages and changes in wages for three groups - sectoral bargainers and individual bargainers, comprising orienters, and nonorienters - and in passing also provide some new information on wage levels under firm-level bargaining.

What do we find? Apart from confirming that industry-wide collective bargaining has been in retreat in Germany, this update also suggests that it continues to decline. That said, there is every indication that the informal following of sectoral agreements is not merely commonplace but also on the increase. There is even the suggestion that it may be increasing most where sectoral bargaining is most in decline, even if at this descriptive level (i.e. simply lumping together formal and informal sectoral bargaining) it is seldom sufficient to reverse the decline. Turning to the issue of alignment, however, the evidence is necessarily mixed. In cross section, it is the case that those paid according to sectoral agreements earn most and that some way behind them come orienting firms that pay somewhat more than their non-orienting counterparts. There is also evidence from changes in wages attendant upon changes in status - for the three-year period case - that those joining sectoral agreements 'gain' while leavers 'lose'. Moreover, orienters tend to do better than nonorienters in each case. Among leavers, for example, orienters tend to stay in closer contention with stayers, while for joiners they also enjoy a slight edge. The results for leavers hold up over a longer observation window (i.e. the 4-year period sequence) but this is not true for joiners among whom ex-orienters end up with the lowest increases. We have speculated on possible reasons for these results. Further progress in this area requires micro examination of individual contracts. Meantime, the bottom line is that in neither frequency nor duration is the compensation offered by orientation other than partial. 


\section{Endnotes}

1. As a prime case in point, the decentralization debate has tended to skirt one obvious form of decentralization, namely a growth in firm-level bargaining on the Anglo-Saxon pattern. Moreover, the subsequent stagnation or even decline in firm-level bargaining has also been neglected, although it has been conjectured that is linked to contractual innovations in sectoral bargaining such as opening clauses and pacts for employment and competitiveness.

2. This part of the questionnaire inquiring about collective bargaining status also asks firms following a multi-employer or single-employer agreement whether or not they paid higher wages than laid down in the respective tariff agreement. We do not use this information, but for an analysis of this 'wage cushion', see Jung and Schnabel (2009).

3. Note that the differences in the mean values reported in the last two columns of Table 10 are statistically different at .0 .5 level or better in all cases. By contrast, the wage differences in favor of orienting firms over non-orienting firms are statistically significant in two (out of 11) cases.

4. The sequences ( $s c b-f c b-f c b)$ and ( $f c b-s c b-s c b)$, where ' $f c b$ ' denotes the presence of a firm agreement, have also been ignored in the literature and are strictly outside of the remit of the present paper. As a practical matter, the number of transitions is very much lower here. 


\section{References}

Addison, J.T., Burton, J. (1977). 'The institutionalist analysis of wage inflation: a cautionary note'. Research in Labor Economics, 1: 333-376.

Addison, J.T., Bryson, A., Teixeira, P., Pahnke, A., Bellmann, L. (2011). 'The state of collective bargaining and worker representation in Germany: the erosion continues'. Unpublished Paper, Department of Economics, University of South Carolina.

Bispinck, R., Dribbusch, H., Schulten, T. (2010). 'German collective bargaining in a European perspective. Continuous erosion or re-stabilization of multi-employer agreements?' Wirtschafts- und Sozialwissenschaftliches Institut, Düsseldorf: Hans Böckler Stiftung.

Doellgast, V., Greer, I. (2007). 'Vertical disintegration and the disorganization of German industrial relations'. British Journal of Industrial Relations, 45: 55-76.

Ellguth, P., Kohaut, S. (2010). 'Tarifbindung und betriebliche Interessenvertretung - aktuelle Ergebnisse aus dem IAB-Betriebspanel 2009'. WSI-Mitteilungen, 63: 204-209.

Ellguth,P., Kohaut,S. (2011). 'Tarifbindung und tarifliche Interessenvertretung: Aktuelle Ergebnisse aus dem IAB-Betriebspanel.' WSI-Mitteilungen, 64: 242-247

Fischer, G., Janik, F., Müller, D., Schmucker, A. (2009). 'The IAB establishment panel: things users should know'. Schmollers Jahrbuch, 129: 133-148.

Frege, C.M. (2003). 'Transforming German workplace relations: quo vadis cooperation?' Economic and Industrial Democracy, 24: 317-347.

Gürtzgen, N. (2006). 'The effect of firm- and industry-level contracts on wages: evidence from longitudinal linked employer-employee data.' ZEW Discussion Paper No. 06-82. Mannheim: Zentrum für Europäische Wirtschafts forschung/ZEW.

Haipeter, T., Lehndorff, S. (2009). 'Collective bargaining on employment'. Working Paper No. 3, Industrial Relations Department, Geneva: International Labour Office.

Hassel, A. (1999). 'The erosion of the German system of industrial relations'. British Journal of Industrial Relations, 37: 483-505.

Hassel, A. (2002). 'The erosion continues: reply [to Klikauer]'. British Journal of Industrial Relations, 40: 309-317.

Jung, S., Schnabel, C. (2009). 'Paying more than necessary? The wage cushion in Germany'. Discussion Paper No. 63, Friedrich-Alexander-Universität Erlangen-Nürnberg.

Kohaut, S., Schnabel, C. (2003a). 'Tarifverträge - nein danke? Ausmaß und Einflussfaktoren der Tarifbindung west- und ostdeutscher Betriebe'. Jahrbücher für Nationalökonomie und Statistik, 223: 312-333. 
Kohaut, S., Schnabel, C. (2003b). 'Zur Erosion des Flächentarifvertrags: Ausmaß, Einflussfaktoren und Gegenmaßnahmen'. Industrielle Beziehungen, 10: 193-219.

Kohaut, S., Ellguth, P. (2008). 'Neue gegründete Betriebe sind seltener tarifgebunden'. IAB-Kurzbericht 16: $1-8$.

Massa-Wirth, H., Niechoj, T. (2004). 'Supranational coordination but national fragmentation: interplay of European economic policy and firm-level pacts in Germany'. Düsseldorf: Das Wirtschafts- und Sozialwissenschaftliche Institut (WSI) der Hans-Böckler-Stiftung. Available online at http://poloekdvpw.mpifg.de/e_documents/publikationen/Massa-wirth\%20Niechoj\%20-

\%20Supranational\%20Coordination.pdf

Ochel, W. (2005). 'Decentralizing wage bargaining in Germany - a way to increase employment?' Labor, 19: 91-121.

Streeck, W., Thelen, K. (2004). 'Introduction: institutional change in advanced political economies'. In W. Streeck and K. Thelen (eds.), Beyond Continuity: Institutional Change in Advanced Political Economies. New York: Oxford University Press, pp. 1-39.

Thelen, K., van Wijnbergen, C. (2003). 'The paradox of globalization: labour relations in Germany and beyond'. Comparative Political Studies, 36: 859-880.

Visser, J. (2006). 'More holes in the bucket: twenty years of European Integration and organized labor'. Comparative Labor Law and Policy Journal, 26: 477-522. 
Table 1: Collective Bargaining Coverage by Establishment (all Germany), 2000-2010, Weighted Data

\begin{tabular}{|c|c|c|c|c|}
\hline Year & $\begin{array}{c}\text { Sectoral } \\
\text { agreement }\end{array}$ & Firm agreement & $\begin{array}{c}\text { Not covered by a } \\
\text { collective agreement but } \\
\text { oriented toward one }\end{array}$ & $\begin{array}{c}\text { Neither covered by a } \\
\text { collective agreement nor } \\
\text { oriented }\end{array}$ \\
\hline 2000 & 49.3 & 3.8 & 24.2 & 22.7 \\
\hline 2001 & 48.7 & 4.3 & 25.3 & 21.7 \\
\hline 2002 & 47.3 & 3.8 & 25.5 & 23.5 \\
\hline 2003 & 46.0 & 3.8 & 26.9 & 26.4 \\
\hline 2004 & 44.9 & 3.6 & 25.2 & 28.7 \\
\hline 2005 & 42.5 & 3.8 & 25.1 & 27.0 \\
\hline 2006 & 41.4 & 3.5 & 28.0 & 26.9 \\
\hline 2007 & 39.5 & 3.7 & 29.8 & 28.3 \\
\hline 2008 & 39.0 & 3.9 & 28.7 & 26.6 \\
\hline 2009 & 40.1 & 4.4 & 28.9 & 29.6 \\
\hline 2010 & 37.7 & 3.3 & 29.5 & \\
\hline
\end{tabular}

Note: We exclude all establishments over the relevant observation period that had less than five employees at all points.

Table 2: Collective Bargaining Coverage by Employment (all Germany), 2000-2010, Weighted Data

\begin{tabular}{|c|c|c|c|c|}
\hline Year & $\begin{array}{c}\text { Sectoral } \\
\text { agreement }\end{array}$ & Firm agreement & $\begin{array}{c}\text { Not covered by a } \\
\text { collective agreement but } \\
\text { oriented toward one }\end{array}$ & $\begin{array}{c}\text { Neither covered by a } \\
\text { collective agreement nor } \\
\text { oriented }\end{array}$ \\
\hline 2000 & 58.9 & 7.5 & 17.9 & 15.7 \\
\hline 2001 & 59.0 & 8.2 & 18.6 & 14.2 \\
\hline 2002 & 58.1 & 8.0 & 18.6 & 15.3 \\
\hline 2003 & 57.3 & 8.7 & 18.9 & 15.1 \\
\hline 2004 & 56.4 & 8.0 & 18.1 & 17.5 \\
\hline 2005 & 54.4 & 8.2 & 19.0 & 18.4 \\
\hline 2006 & 52.0 & 9.1 & 20.5 & 18.4 \\
\hline 2007 & 50.9 & 8.1 & 22.7 & 18.4 \\
\hline 2008 & 49.9 & 8.7 & 22.5 & 18.8 \\
\hline 2009 & 50.0 & 9.6 & 21.9 & 18.5 \\
\hline 2010 & 49.3 & 8.2 & 22.4 & 20.1 \\
\hline
\end{tabular}

Note: See Table 1. 
Table 3: Collective Bargaining Coverage by Establishment for Western and Eastern Germany, 2000-2010, Weighted Data

\begin{tabular}{|c|c|c|c|c|c|c|c|c|}
\hline & \multicolumn{4}{|c|}{ Western Germany } & \multicolumn{3}{|c|}{ Eastern Germany } \\
\cline { 2 - 9 } Year & $\begin{array}{c}\text { Sectoral } \\
\text { agreement }\end{array}$ & $\begin{array}{c}\text { Firm } \\
\text { agreement }\end{array}$ & $\begin{array}{c}\text { Not } \\
\text { covered by } \\
\text { a collective } \\
\text { agreement } \\
\text { but } \\
\text { oriented } \\
\text { toward one }\end{array}$ & $\begin{array}{c}\text { Neither } \\
\text { covered } \\
\text { by a } \\
\text { collective } \\
\text { agreement } \\
\text { nor } \\
\text { oriented }\end{array}$ & $\begin{array}{c}\text { Sectoral } \\
\text { agreement }\end{array}$ & $\begin{array}{c}\text { Firm } \\
\text { agreement }\end{array}$ & $\begin{array}{c}\text { Not } \\
\text { covered by } \\
\text { a collective } \\
\text { agreement } \\
\text { but } \\
\text { bovered } \\
\text { by a } \\
\text { collective } \\
\text { agreeme } \\
\text { nt nor } \\
\text { oriented }\end{array}$ \\
\hline 2000 & 54.8 & 3.4 & 21.6 & 20.2 & 30.1 & 5.2 & 33.1 & 31.6 \\
\hline 2001 & 54.5 & 3.4 & 23.0 & 19.1 & 28.2 & 7.4 & 33.4 & 31.0 \\
\hline 2002 & 53.3 & 3.3 & 22.1 & 21.3 & 25.7 & 5.6 & 37.6 & 31.1 \\
\hline 2003 & 51.8 & 3.1 & 25.2 & 20.0 & 25.2 & 6.5 & 33.2 & 35.2 \\
\hline 2004 & 50.4 & 3.2 & 23.2 & 23.2 & 25.1 & 5.2 & 32.0 & 37.8 \\
\hline 2005 & 47.3 & 3.5 & 23.5 & 25.7 & 25.6 & 4.7 & 30.7 & 39.1 \\
\hline 2006 & 45.2 & 3.0 & 27.3 & 24.6 & 27.4 & 5.7 & 30.9 & 36.1 \\
\hline 2007 & 43.6 & 3.1 & 28.8 & 24.5 & 24.1 & 6.1 & 33.8 & 36.0 \\
\hline 2008 & 42.8 & 3.2 & 28.0 & 25.9 & 25.8 & 6.1 & 31.2 & 36.9 \\
\hline 2009 & 44.2 & 4.2 & 27.7 & 23.8 & 25.0 & 5.0 & 33.3 & 36.7 \\
\hline 2010 & 42.0 & 3.0 & 28.2 & 26.8 & 21.8 & 4.2 & 34.2 & 39.8 \\
\hline
\end{tabular}

Note: See Table 1.

Table 4: Collective Bargaining Coverage by Employment for Western and Eastern Germany, 2000-2010, Weighted data

\begin{tabular}{|c|c|c|c|c|c|c|c|c|}
\hline \multirow[b]{2}{*}{ Year } & \multicolumn{4}{|c|}{ Western Germany } & \multicolumn{4}{|c|}{ Eastern Germany } \\
\hline & $\begin{array}{c}\text { Sectoral } \\
\text { agreement }\end{array}$ & $\begin{array}{c}\text { Firm } \\
\text { agreement }\end{array}$ & $\begin{array}{c}\text { Not } \\
\text { covered by } \\
\text { a collective } \\
\text { agreement } \\
\text { but } \\
\text { oriented } \\
\text { toward one }\end{array}$ & $\begin{array}{c}\text { Neither } \\
\text { covered } \\
\text { by a } \\
\text { collective } \\
\text { agreement } \\
\text { nor } \\
\text { oriented }\end{array}$ & $\begin{array}{c}\text { Sectoral } \\
\text { agreement }\end{array}$ & $\begin{array}{c}\text { Firm } \\
\text { agreement }\end{array}$ & $\begin{array}{c}\text { Not } \\
\text { covered by } \\
\text { a collective } \\
\text { agreement } \\
\text { but } \\
\text { oriented } \\
\text { toward one }\end{array}$ & $\begin{array}{c}\text { Neither } \\
\text { covered } \\
\text { by a } \\
\text { collective } \\
\text { agreeme } \\
\text { nt nor } \\
\text { oriented }\end{array}$ \\
\hline 2000 & 62.5 & 6.9 & 16.3 & 14.3 & 40.7 & 10.3 & 26.1 & 22.8 \\
\hline 2001 & 63.0 & 7.4 & 17.2 & 12.4 & 39.8 & 12.3 & 25.5 & 22.4 \\
\hline 2002 & 62.3 & 7.1 & 17.1 & 13.5 & 36.8 & 12.7 & 26.3 & 24.2 \\
\hline 2003 & 61.1 & 8.0 & 17.6 & 13.3 & 37.9 & 11.9 & 25.7 & 24.4 \\
\hline 2004 & 60.2 & 7.4 & 17.0 & 15.5 & 37.3 & 11.0 & 24.2 & 27.5 \\
\hline 2005 & 57.9 & 7.6 & 17.8 & 16.8 & 37.2 & 11.3 & 25.0 & 26.5 \\
\hline 2006 & 54.9 & 8.5 & 19.8 & 16.8 & 37.2 & 12.1 & 24.1 & 26.6 \\
\hline 2007 & 53.9 & 7.3 & 22.1 & 16.7 & 34.9 & 11.9 & 26.2 & 26.9 \\
\hline 2008 & 53.0 & 8.0 & 21.8 & 17.2 & 34.6 & 12.2 & 26.3 & 26.8 \\
\hline 2009 & 53.1 & 9.1 & 20.9 & 16.9 & 34.0 & 12.1 & 27.3 & 26.6 \\
\hline 2010 & 52.8 & 7.5 & 21.4 & 18.3 & 31.2 & 11.5 & 27.7 & 29.6 \\
\hline
\end{tabular}

Note: See Table 1. 
Table 5: Collective Bargaining Coverage by Establishment for Different Sectors, 2000-2010, Weighted Data

\begin{tabular}{|c|c|c|c|c|c|}
\hline $\begin{array}{l}\text { Industry } \\
\text { aggregate }\end{array}$ & Year & $\begin{array}{c}\text { Sectoral } \\
\text { agreement }\end{array}$ & $\begin{array}{c}\text { Firm } \\
\text { agreement }\end{array}$ & $\begin{array}{c}\text { Not covered by a } \\
\text { collective agreement } \\
\text { but oriented toward one }\end{array}$ & $\begin{array}{c}\text { Neither covered by a } \\
\text { collective agreement nor } \\
\text { oriented }\end{array}$ \\
\hline \multirow[t]{11}{*}{ Manufacturing } & 2000 & 45.6 & 4.3 & 31.6 & 18.5 \\
\hline & 2001 & 48.5 & 5.7 & 27.7 & 18.2 \\
\hline & 2002 & 48.9 & 3.7 & 30.4 & 17.0 \\
\hline & 2003 & 48.7 & 3.6 & 27.2 & 20.5 \\
\hline & 2004 & 45.6 & 3.7 & 29.1 & 21.6 \\
\hline & 2005 & 42.9 & 3.9 & 26.9 & 26.3 \\
\hline & 2006 & 41.0 & 4.0 & 32.9 & 22.2 \\
\hline & 2007 & 38.2 & 5.0 & 32.8 & 24.0 \\
\hline & 2008 & 36.1 & 5.2 & 33.8 & 24.8 \\
\hline & 2009 & 38.5 & 4.6 & 31.2 & 25.7 \\
\hline & 2010 & 33.5 & 4.1 & 35.5 & 26.9 \\
\hline \multirow[t]{11}{*}{ Construction } & 2000 & 71.7 & 2.9 & 17.3 & 8.1 \\
\hline & 2001 & 66.7 & 2.7 & 18.9 & 11.7 \\
\hline & 2002 & 65.8 & 2.5 & 23.1 & 8.6 \\
\hline & 2003 & 64.2 & 2.4 & 23.5 & 9.8 \\
\hline & 2004 & 67.5 & 2.2 & 19.3 & 11.0 \\
\hline & 2005 & 64.5 & 2.2 & 20.5 & 12.7 \\
\hline & 2006 & 66.7 & 2.6 & 20.8 & 9.9 \\
\hline & 2007 & 68.5 & 1.7 & 20.8 & 9.0 \\
\hline & 2008 & 69.0 & 2.9 & 17.4 & 10.7 \\
\hline & 2009 & 70.9 & 3.3 & 16.1 & 9.6 \\
\hline & 2010 & 68.9 & 1.1 & 18.4 & 11.5 \\
\hline \multirow{11}{*}{$\begin{array}{l}\text { Trade, } \\
\text { Transport, and } \\
\text { Finance }\end{array}$} & 2000 & 57.0 & 4.3 & 19.9 & 18.8 \\
\hline & 2001 & 57.1 & 5.4 & 21.6 & 15.9 \\
\hline & 2002 & 52.9 & 4.2 & 24.3 & 18.7 \\
\hline & 2003 & 52.1 & 4.5 & 24.8 & 18.6 \\
\hline & 2004 & 49.6 & 4.4 & 25.0 & 21.0 \\
\hline & 2005 & 45.0 & 5.0 & 25.2 & 24.8 \\
\hline & 2006 & 43.9 & 4.6 & 28.3 & 23.2 \\
\hline & 2007 & 42.1 & 4.3 & 29.9 & 23.7 \\
\hline & 2008 & 41.6 & 3.5 & 30.6 & 24.3 \\
\hline & 2009 & 39.1 & 5.1 & 30.6 & 25.1 \\
\hline & 2010 & 36.3 & 4.5 & 29.6 & 29.6 \\
\hline
\end{tabular}




\begin{tabular}{|c|c|c|c|c|c|}
\hline \multirow{11}{*}{$\begin{array}{l}\text { Business } \\
\text { Services }\end{array}$} & 2000 & 14.5 & 3.3 & 33.3 & 48.9 \\
\hline & 2001 & 15.2 & 3.0 & 29.2 & 52.6 \\
\hline & 2002 & 14.6 & 2.2 & 24.2 & 59.0 \\
\hline & 2003 & 16.1 & 4.6 & 31.2 & 48.1 \\
\hline & 2004 & 16.0 & 2.6 & 26.5 & 54.8 \\
\hline & 2005 & 14.6 & 1.8 & 25.2 & 58.4 \\
\hline & 2006 & 13.0 & 2.5 & 30.1 & 54.4 \\
\hline & 2007 & 14.0 & 2.8 & 29.5 & 53.7 \\
\hline & 2008 & 12.4 & 4.1 & 27.0 & 56.5 \\
\hline & 2009 & 17.4 & 4.0 & 30.8 & 47.8 \\
\hline & 2010 & 16.6 & 2.3 & 30.0 & 51.2 \\
\hline \multirow[t]{11}{*}{ Other Services } & 2000 & 46.1 & 3.8 & 23.0 & 27.0 \\
\hline & 2001 & 44.7 & 3.5 & 32.7 & 19.2 \\
\hline & 2002 & 48.1 & 5.7 & 26.2 & 20.0 \\
\hline & 2003 & 42.5 & 3.1 & 29.8 & 24.7 \\
\hline & 2004 & 43.8 & 4.2 & 25.2 & 26.8 \\
\hline & 2005 & 44.3 & 4.4 & 26.9 & 24.4 \\
\hline & 2006 & 42.1 & 2.9 & 27.0 & 28.0 \\
\hline & 2007 & 35.9 & 3.8 & 34.3 & 26.1 \\
\hline & 2008 & 39.1 & 3.6 & 31.3 & 26.1 \\
\hline & 2009 & 40.7 & 3.3 & 31.7 & 24.3 \\
\hline & 2010 & 38.9 & 2.0 & 32.2 & 26.9 \\
\hline
\end{tabular}

Note: There is a change in industry classification in 2009 , see section II. 
Table 6: Collective Bargaining Coverage by Employment for Different Sectors, 2000-2010, Weighted Data

\begin{tabular}{|c|c|c|c|c|c|}
\hline $\begin{array}{l}\text { Industry } \\
\text { aggregate }\end{array}$ & Year & $\begin{array}{c}\text { Sectoral } \\
\text { agreement }\end{array}$ & $\begin{array}{c}\text { Firm } \\
\text { agreement }\end{array}$ & $\begin{array}{c}\text { Not covered by a } \\
\text { collective agreement } \\
\text { but oriented toward } \\
\text { one }\end{array}$ & $\begin{array}{l}\text { Neither covered by a } \\
\text { collective agreement nor } \\
\text { oriented }\end{array}$ \\
\hline \multirow[t]{11}{*}{ Manufacturing } & 2000 & 64.3 & 7.0 & 18.2 & 10.5 \\
\hline & 2001 & 64.1 & 9.8 & 17.1 & 9.0 \\
\hline & 2002 & 65.5 & 8.7 & 17.0 & 8.8 \\
\hline & 2003 & 64.4 & 9.1 & 17.0 & 9.6 \\
\hline & 2004 & 62.9 & 7.5 & 17.8 & 11.8 \\
\hline & 2005 & 59.9 & 9.1 & 18.8 & 12.2 \\
\hline & 2006 & 56.7 & 11.1 & 20.9 & 11.3 \\
\hline & 2007 & 56.3 & 10.2 & 21.2 & 12.3 \\
\hline & 2008 & 55.9 & 10.3 & 20.9 & 12.9 \\
\hline & 2009 & 54.2 & 10.7 & 20.8 & 14.3 \\
\hline & 2010 & 52.7 & 11.7 & 20.8 & 14.8 \\
\hline \multirow[t]{11}{*}{ Construction } & 2000 & 74.5 & 4.3 & 15.3 & 6.0 \\
\hline & 2001 & 72.2 & 4.7 & 16.0 & 7.1 \\
\hline & 2002 & 71.3 & 4.5 & 18.0 & 6.1 \\
\hline & 2003 & 72.5 & 3.9 & 17.9 & 5.7 \\
\hline & 2004 & 71.0 & 4.2 & 17.5 & 7.3 \\
\hline & 2005 & 70.4 & 4.1 & 17.5 & 8.1 \\
\hline & 2006 & 71.6 & 4.3 & 16.9 & 7.2 \\
\hline & 2007 & 73.5 & 3.1 & 15.7 & 7.7 \\
\hline & 2008 & 71.4 & 5.2 & 15.1 & 8.4 \\
\hline & 2009 & 74.2 & 3.7 & 14.0 & 8.2 \\
\hline & 2010 & 72.8 & 3.0 & 15.2 & 9.0 \\
\hline \multirow{11}{*}{$\begin{array}{l}\text { Trade, } \\
\text { Transport, and } \\
\text { Finance }\end{array}$} & 2000 & 63.3 & 8.7 & 14.5 & 13.4 \\
\hline & 2001 & 64.4 & 9.6 & 15.4 & 10.5 \\
\hline & 2002 & 61.6 & 8.7 & 17.2 & 12.5 \\
\hline & 2003 & 60.1 & 11.4 & 16.2 & 12.3 \\
\hline & 2004 & 58.3 & 10.1 & 17.2 & 14.4 \\
\hline & 2005 & 54.9 & 9.3 & 18.9 & 16.9 \\
\hline & 2006 & 51.3 & 9.1 & 22.0 & 17.6 \\
\hline & 2007 & 49.5 & 7.3 & 24.8 & 18.5 \\
\hline & 2008 & 46.3 & 8.2 & 26.1 & 19.5 \\
\hline & 2009 & 43.9 & 9.6 & 25.0 & 21.5 \\
\hline & 2010 & 42.6 & 7.0 & 26.5 & 23.9 \\
\hline
\end{tabular}




\begin{tabular}{|c|c|c|c|c|c|}
\hline \multirow{11}{*}{$\begin{array}{l}\text { Business } \\
\text { Services }\end{array}$} & 2000 & 35.6 & 8.3 & 21.9 & 34.3 \\
\hline & 2001 & 33.3 & 6.0 & 22.8 & 37.9 \\
\hline & 2002 & 30.1 & 5.4 & 21.9 & 42.6 \\
\hline & 2003 & 30.4 & 7.3 & 24.7 & 37.7 \\
\hline & 2004 & 33.9 & 9.1 & 17.2 & 39.7 \\
\hline & 2005 & 37.4 & 7.1 & 17.2 & 38.4 \\
\hline & 2006 & 35.1 & 9.2 & 17.2 & 38.5 \\
\hline & 2007 & 38.5 & 7.3 & 20.6 & 33.7 \\
\hline & 2008 & 37.9 & 8.4 & 19.1 & 34.6 \\
\hline & & & & & \\
\hline & 2009 & 45.1 & 10.3 & 17.5 & 27.2 \\
\hline & 2010 & 49.2 & 7.0 & 16.6 & 27.2 \\
\hline \multirow[t]{11}{*}{ Other Services } & 2000 & 46.7 & 7.9 & 23.6 & 21.9 \\
\hline & 2001 & 50.1 & 5.8 & 29.2 & 14.8 \\
\hline & 2002 & 50.0 & 10.2 & 24.1 & 15.6 \\
\hline & 2003 & 49.3 & 5.6 & 25.9 & 19.1 \\
\hline & 2004 & 49.3 & 5.4 & 23.3 & 22.0 \\
\hline & 2005 & 47.2 & 7.0 & 22.9 & 22.9 \\
\hline & 2006 & 48.3 & 6.4 & 22.2 & 23.1 \\
\hline & 2007 & 41.1 & 7.7 & 29.0 & 22.2 \\
\hline & 2008 & 44.7 & 8.3 & 27.5 & 19.5 \\
\hline & 2009 & 46.7 & 8.9 & 26.2 & 18.2 \\
\hline & 2010 & 45.4 & 6.0 & 26.8 & 21.8 \\
\hline
\end{tabular}

Note: See Table 5. 
Table 7: Collective Bargaining Coverage by Establishment for Establishments of Different Size, 2000-2010, Weighted Data

\begin{tabular}{|c|c|c|c|c|c|c|c|c|c|c|c|c|}
\hline \multirow[b]{2}{*}{ Year } & \multicolumn{4}{|c|}{ Establishments with 5 to 49 employees } & \multicolumn{4}{|c|}{ Establishments with 50 to 249 employees } & \multicolumn{4}{|c|}{ Establishments with at least 250 employees } \\
\hline & $\begin{array}{r}\text { Sectoral } \\
\text { agreement }\end{array}$ & $\begin{array}{r}\text { Firm } \\
\text { agreement }\end{array}$ & $\begin{array}{r}\text { Not covered by a } \\
\text { collective } \\
\text { agreement but } \\
\text { oriented toward one }\end{array}$ & $\begin{array}{r}\text { Neither } \\
\text { covered by a } \\
\text { collective } \\
\text { agreement nor } \\
\text { oriented }\end{array}$ & $\begin{array}{r}\text { Sectoral } \\
\text { agreement }\end{array}$ & $\begin{array}{r}\text { Firm } \\
\text { agreement }\end{array}$ & $\begin{array}{r}\text { Not covered by a } \\
\text { collective agreement } \\
\text { but oriented toward } \\
\text { one }\end{array}$ & $\begin{array}{r}\text { Neither covered } \\
\text { by a collective } \\
\text { agreement nor } \\
\text { oriented }\end{array}$ & $\begin{array}{r}\text { Sectoral } \\
\text { agreement }\end{array}$ & $\begin{array}{r}\text { Firm } \\
\text { agreement }\end{array}$ & $\begin{array}{r}\text { Not covered by } \\
\text { a collective } \\
\text { agreement but } \\
\text { oriented } \\
\text { toward one }\end{array}$ & $\begin{array}{r}\text { Neither } \\
\text { covered by a } \\
\text { collective } \\
\text { agreement } \\
\text { nor oriented }\end{array}$ \\
\hline 2000 & 48.7 & 3.3 & 24.7 & 23.3 & 52.5 & 8.8 & 20.8 & 17.9 & 70.1 & 13.2 & 8.4 & 8.3 \\
\hline 2001 & 47.9 & 4.0 & 25.6 & 22.6 & 54.8 & 6.9 & 24.1 & 14.2 & 71.5 & 13.3 & 9.4 & 5.8 \\
\hline 2002 & 46.4 & 3.3 & 26.0 & 24.3 & 54.3 & 8.2 & 21.8 & 15.8 & 71.2 & 12.9 & 9.6 & 6.3 \\
\hline 2003 & 45.1 & 3.2 & 27.6 & 24.1 & 54.3 & 9.5 & 21.2 & 15.0 & 69.2 & 13.4 & 9.6 & 7.9 \\
\hline 2004 & 44.0 & 3.1 & 25.8 & 27.1 & 52.0 & 8.6 & 19.9 & 19.4 & 69.6 & 13.5 & 9.3 & 7.7 \\
\hline 2005 & 41.4 & 3.2 & 25.6 & 29.8 & 51.9 & 8.8 & 21.0 & 18.3 & 68.4 & 13.9 & 9.7 & 7.9 \\
\hline 2006 & 40.5 & 3.0 & 28.7 & 27.8 & 48.7 & 8.8 & 22.3 & 20.3 & 63.5 & 15.7 & 12.3 & 8.5 \\
\hline 2007 & 38.5 & 3.2 & 30.4 & 27.9 & 46.3 & 8.5 & 26.0 & 19.2 & 64.3 & 12.6 & 14.4 & 8.6 \\
\hline 2008 & 38.0 & 3.2 & 29.5 & 29.3 & 46.9 & 9.8 & 22.9 & 20.5 & 60.4 & 13.3 & 16.5 & 9.9 \\
\hline 2009 & 39.1 & 3.9 & 29.5 & 27.4 & 48.0 & 8.4 & 23.7 & 19.9 & 59.8 & 14.4 & 13.9 & 11.9 \\
\hline 2010 & 36.5 & 2.7 & 30.1 & 30.7 & 46.4 & 7.4 & 25.6 & 20.6 & 61.7 & 14.0 & 13.5 & 10.8 \\
\hline
\end{tabular}

Note: See Table 1. 
Table 8: Collective Bargaining Coverage by Employment for Establishments of Different Size, 2000-2010, Weighted Data

\begin{tabular}{|c|c|c|c|c|c|c|c|c|c|c|c|c|}
\hline \multirow[b]{2}{*}{ Year } & \multicolumn{4}{|c|}{ Establishments with 5 to 49 employees } & \multicolumn{4}{|c|}{ Establishments with 50 to 249 employees } & \multicolumn{4}{|c|}{ Establishments with at least 250 employees } \\
\hline & $\begin{array}{r}\text { Sectoral } \\
\text { agreement }\end{array}$ & $\begin{array}{r}\text { Firm } \\
\text { agreement }\end{array}$ & $\begin{array}{r}\text { Not covered } \\
\text { by a collective } \\
\text { agreement but } \\
\text { oriented } \\
\text { toward one }\end{array}$ & $\begin{array}{r}\text { Neither } \\
\text { covered by a } \\
\text { collective } \\
\text { agreement nor } \\
\text { oriented }\end{array}$ & $\begin{array}{r}\text { Sectoral } \\
\text { agreement }\end{array}$ & $\begin{array}{r}\text { Firm } \\
\text { agreement }\end{array}$ & $\begin{array}{r}\text { Not covered } \\
\text { by a collective } \\
\text { agreement but } \\
\text { oriented } \\
\text { toward one }\end{array}$ & $\begin{array}{r}\text { Neither } \\
\text { covered by a } \\
\text { collective } \\
\text { agreement nor } \\
\text { oriented }\end{array}$ & $\begin{array}{r}\text { Sectoral } \\
\text { agreement }\end{array}$ & $\begin{array}{r}\text { Firm } \\
\text { agreement }\end{array}$ & $\begin{array}{r}\text { Not covered } \\
\text { by a collective } \\
\text { agreement but } \\
\text { oriented } \\
\text { toward one }\end{array}$ & $\begin{array}{r}\text { Neither } \\
\text { covered by a } \\
\text { collective } \\
\text { agreement nor } \\
\text { oriented }\end{array}$ \\
\hline 2000 & 51.0 & 3.4 & 24.3 & 21.3 & 53.7 & 9.1 & 19.6 & 17.6 & 76.5 & 12.2 & 6.2 & 5.1 \\
\hline 2001 & 50.2 & 4.3 & 24.0 & 21.5 & 57.4 & 7.7 & 22.3 & 12.6 & 74.1 & 14.9 & 6.7 & 4.4 \\
\hline 2002 & 48.2 & 3.7 & 25.3 & 22.8 & 56.1 & 9.1 & 20.2 & 14.6 & 75.3 & 13.6 & 6.8 & 4.3 \\
\hline 2003 & 48.3 & 3.6 & 26.3 & 21.8 & 56.4 & 10.1 & 19.3 & 14.3 & 72.2 & 15.4 & 7.0 & 5.5 \\
\hline 2004 & 46.2 & 3.7 & 25.6 & 24.5 & 54.0 & 9.4 & 18.2 & 18.4 & 75.1 & 13.3 & 6.2 & 5.3 \\
\hline 2005 & 43.4 & 4.1 & 25.5 & 27.1 & 53.0 & 9.8 & 19.8 & 17.4 & 74.1 & 13.4 & 7.4 & 5.1 \\
\hline 2006 & 42.0 & 3.7 & 28.1 & 26.2 & 50.7 & 9.6 & 20.9 & 18.9 & 69.3 & 17.3 & 7.9 & 5.5 \\
\hline 2007 & 39.7 & 3.5 & 30.2 & 26.6 & 48.2 & 9.9 & 23.7 & 18.1 & 70.6 & 13.0 & 10.3 & 6.1 \\
\hline 2008 & 39.5 & 3.7 & 30.4 & 26.4 & 48.4 & 10.8 & 21.3 & 19.5 & 67.2 & 14.1 & 12.1 & 6.6 \\
\hline 2009 & 40.6 & 4.5 & 28.9 & 26.0 & 48.7 & 9.7 & 23.1 & 18.5 & 65.3 & 17.1 & 10.3 & 7.4 \\
\hline 2010 & 37.9 & 3.0 & 30.2 & 28.8 & 48.0 & 8.6 & 23.8 & 19.6 & 68.1 & 15.7 & 8.9 & 7.2 \\
\hline
\end{tabular}

Note: See Table 1. 
Table 9: Real Wage Bill per Employee, 2000-2010, Unweighted Data

\begin{tabular}{|c|c|c|c|c|}
\hline Year & Sectoral agreement & Firm agreement & $\begin{array}{c}\text { Not covered by a } \\
\text { collective agreement } \\
\text { but oriented toward one }\end{array}$ & $\begin{array}{c}\text { Neither covered by a } \\
\text { collective agreement } \\
\text { nor oriented }\end{array}$ \\
\hline 2000 & $2,156.89$ & $2,167.18$ & $1,914.23$ & $1,885.36$ \\
\hline 2001 & $2,147.12$ & $2,128.22$ & $1,904.57$ & $1,975.40$ \\
\hline 2002 & $2,191.69$ & $2,213.86$ & $1,967.43$ & $2,002.04$ \\
\hline 2003 & $2,147.42$ & $2,194.48$ & $1,921.91$ & $1,940.50$ \\
\hline 2004 & $2,151.56$ & $2,239.26$ & $1,930.01$ & $1,904.15$ \\
\hline 2005 & $2,138.19$ & $2,207.73$ & $1,886.75$ & $1,864.75$ \\
\hline 2006 & $2,127.61$ & $2,328.85$ & $1,914.91$ & $1,875.06$ \\
\hline 2007 & $2,100.29$ & $2,199.14$ & $1,837.96$ & $1,810.31$ \\
\hline 2008 & $2,032.12$ & $2,118.46$ & $1,808.80$ & $1,785.61$ \\
\hline 2009 & $2,012.14$ & $2,145.40$ & $1,819.66$ & $1,776.40$ \\
\hline 2010 & $2,062.01$ & $2,197.02$ & $1,844.72$ & $1,794.22$ \\
\hline
\end{tabular}

Notes: The reported figures are per full-time equivalent employee, where a part-time worker is $1 / 2$ of a full-time worker. Real wages refer to year 2000, and were obtained using the inverse of the CPI as a deflator.

Table 10: Real Wage Bill per Employee for Permanent Stayers, 2000-2010, Unweighted Data

\begin{tabular}{|l|c|c|c|c|}
\hline Year & Sectoral agreement & Firm agreement & $\begin{array}{c}\text { Not covered by a } \\
\text { collective agreement } \\
\text { but oriented toward one }\end{array}$ & $\begin{array}{c}\text { Neither covered by a } \\
\text { collective agreement } \\
\text { nor oriented }\end{array}$ \\
\hline 2000 & $2,056.57$ & $2,074.30$ & $1,737.48$ & $1,617.22$ \\
\hline 2001 & $2,035.85$ & $1,970.12$ & $1,723.26$ & $1,628.92$ \\
\hline 2002 & $2,093.53$ & $2,063.26$ & $1,766.87$ & $1,620.24$ \\
\hline 2003 & $2,067.50$ & $2,114.30$ & $1,778.11$ & $1,644.62$ \\
\hline 2004 & $2,085.57$ & $2,061.75$ & $1,811.01$ & $1,618.59$ \\
\hline 2005 & $2,100.23$ & $2,091.12$ & $1,755.02$ & $1,596.95$ \\
\hline 2006 & $2,089.32$ & $2,165.64$ & $1,770.80$ & $1,618.26$ \\
\hline 2007 & $2,169.41$ & $2,137.54$ & $1,722.89$ & $1,608.78$ \\
\hline 2008 & $2,078.46$ & $2,140.78$ & $1,720.91$ & $1,607.35$ \\
\hline 2009 & $2,046.04$ & $2,228.68$ & $1,662.38$ & $1,585.25$ \\
\hline 2010 & $2,087.38$ & $2,283.71$ & $1,715.85$ & $1,602.92$ \\
\hline
\end{tabular}

Note: See Table 9. 
Table 11: Real Wage Bill per Employee in Year t-1, for Sectoral Agreement Stayers, Leavers, and Joiners, Unweighted Data

\begin{tabular}{|l|c|c|}
\hline \multirow{2}{*}{\multicolumn{1}{c|}{ Group }} & \multicolumn{2}{c|}{ Time frame } \\
\cline { 2 - 3 } & Three consecutive years & Four consecutive years \\
\hline Sectoral agreement stayers & $2,179.8$ & $2,206.1$ \\
\hline Orienting leavers & $1,892.8$ & $1,868.4$ \\
\hline Non-orienting leavers & $1,818.2$ & $1,831.6$ \\
\hline Orienting joiners & $1,794.4$ & $1,765.6$ \\
\hline Non-orienting joiners & $1,654.4$ & $1,580.9$ \\
\hline Orienting stayers & $1,922.4$ & $1,924.2$ \\
\hline Non-orienting stayers & $1,726.2$ & $1,859.1$ \\
\hline
\end{tabular}

Notes: For the 3-year sequence we observe the selected establishments in years $t-1, t$, and $t+1$, while for the 4-year case establishments are observed in $t-2, t-1, t$, and $t+1$. The reported values (in year 2000 Euro) are always referred to $t-1$ of the corresponding sequence. See text for full definitions. 
Figure 1: Wage Growth Profile for Sectoral Agreement Stayers and Leavers over Three Consecutive Years

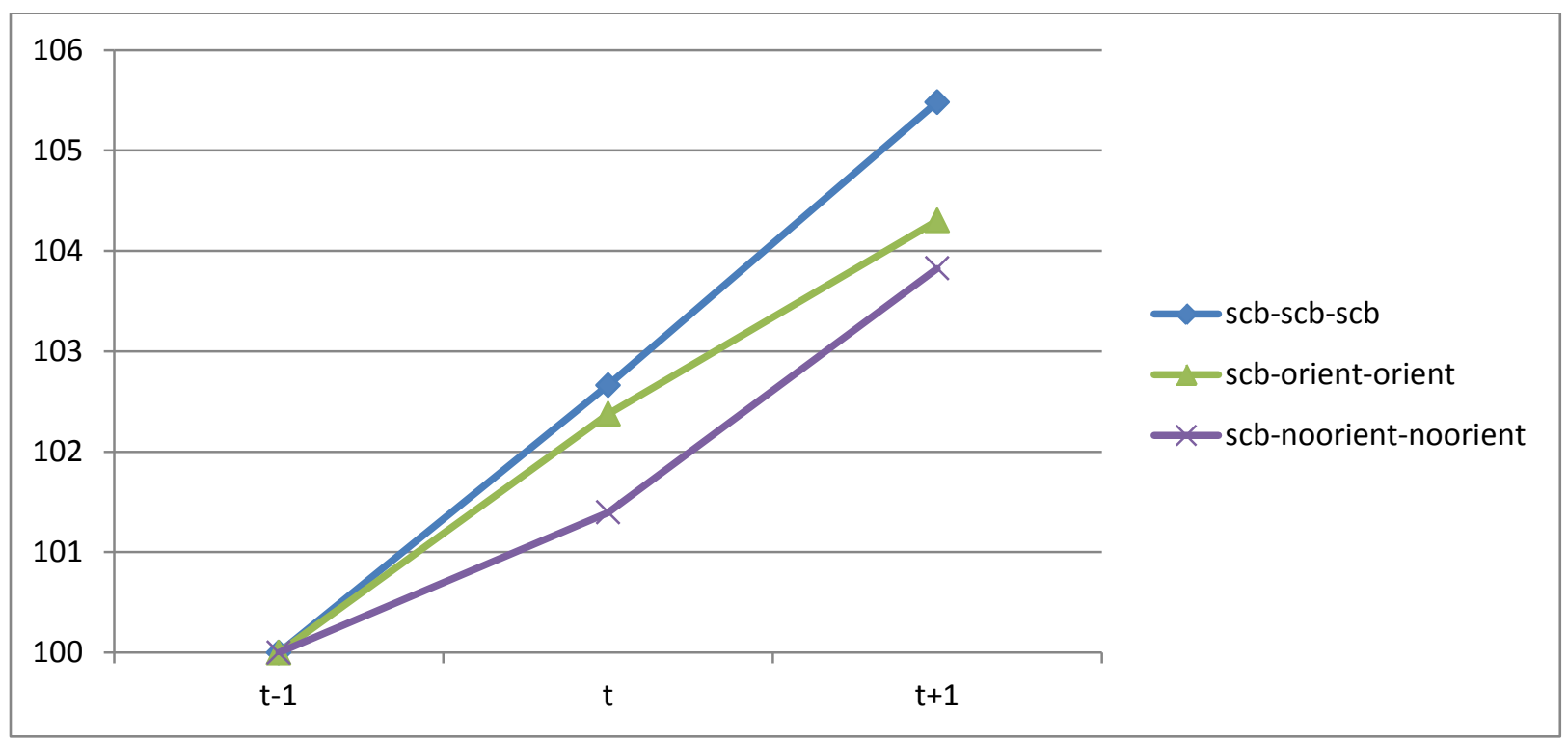

Notes: The three selected establishment groups are observed over three consecutive years, $t-1, t$, and $t+1$, and for each group we compute the real wage growth between $t-1$ and $t$ and between $t$ and $t+1$, respectively. By construction, establishments change status in year $t$. The wage in each group is set to 100 in year $t-1$ so that each line gives the group-specific wage growth over time, that is, one and two years after establishments in the group have been firstly observed. The establishment wage is defined as the real wage bill per full-time equivalent employee (see note to Table 9). The sequences, which are described in the text, are extracted from the 2000-2010 observation window.

Figure 2: Wage Growth Profile for Sectoral Agreement Stayers and Joiners over Three Consecutive Years

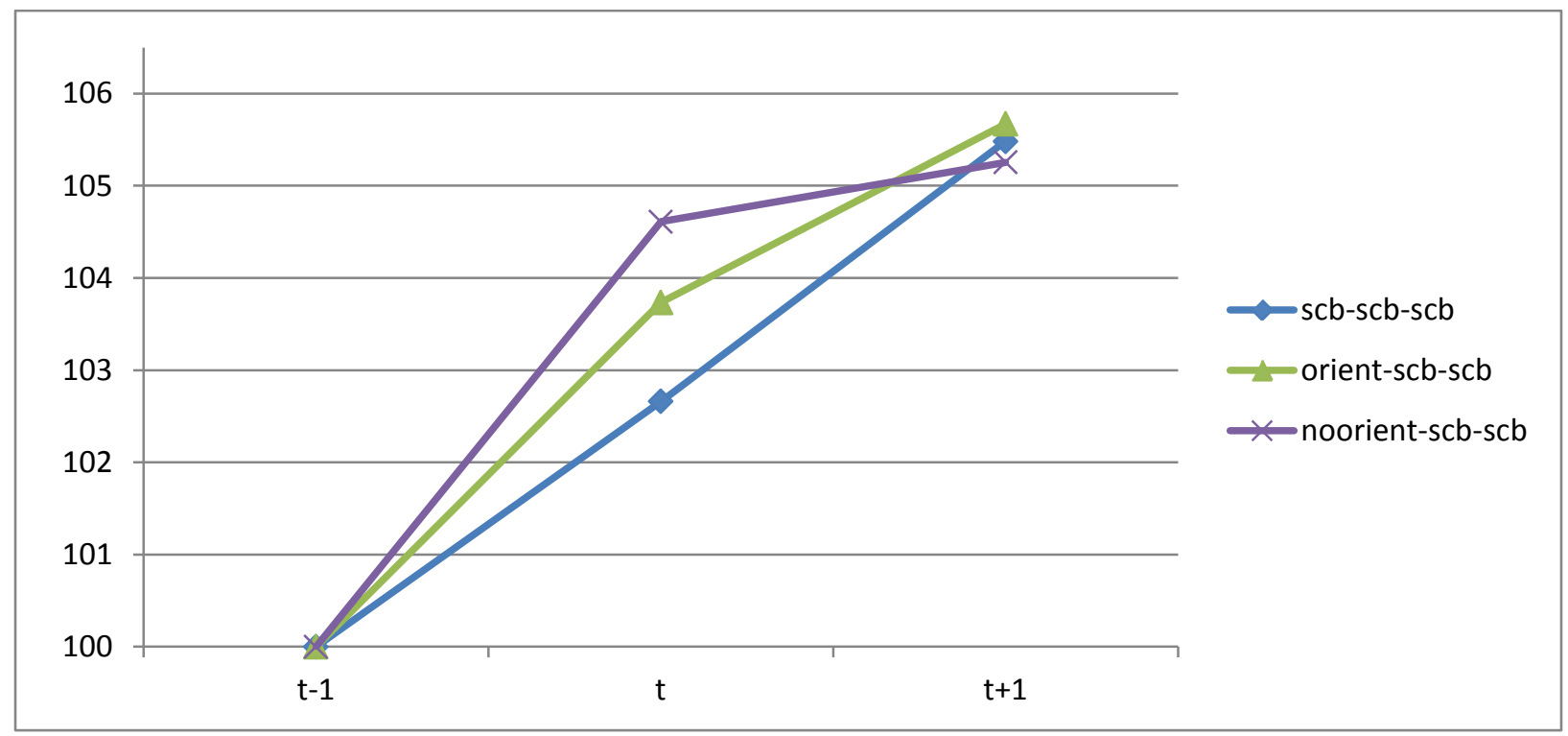

Note: See notes to Figure 1. 
Figure 3: Wage Growth Profile for Sectoral Agreement Stayers and Leavers over Four Consecutive Years

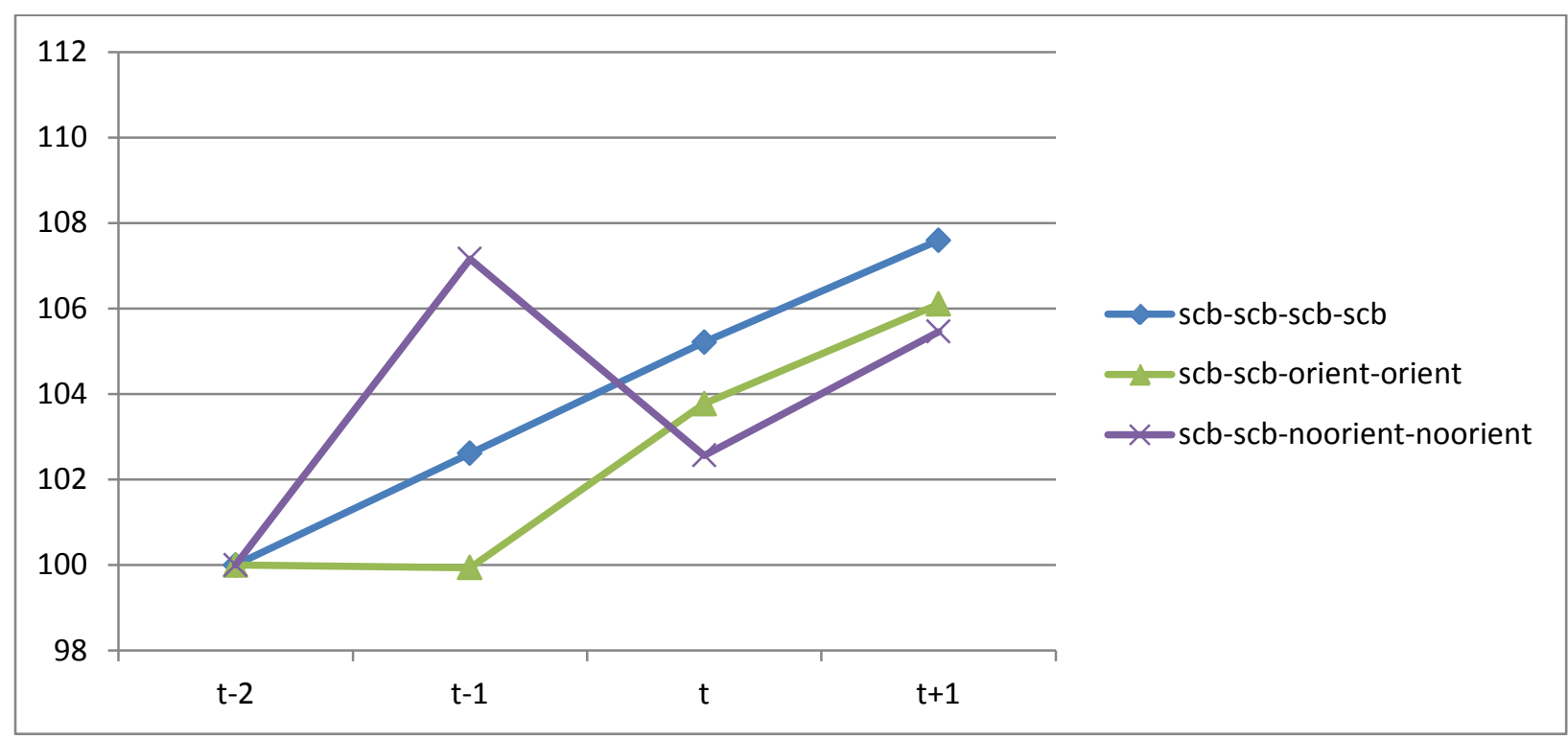

Notes: The three selected establishment groups are observed over four consecutive years $\mathrm{t}-2, \mathrm{t}-1, \mathrm{t}$, and $t+1$, and for each group we compute the real wage growth between $t-2$ and $t-1$, between $t-1$ and $t$ and between $t$ and $t+1$. See notes to Figure 1 .

Figure 4: Wage Growth Profile for Sectoral Agreement Stayers and Joiners over Four Consecutive Years

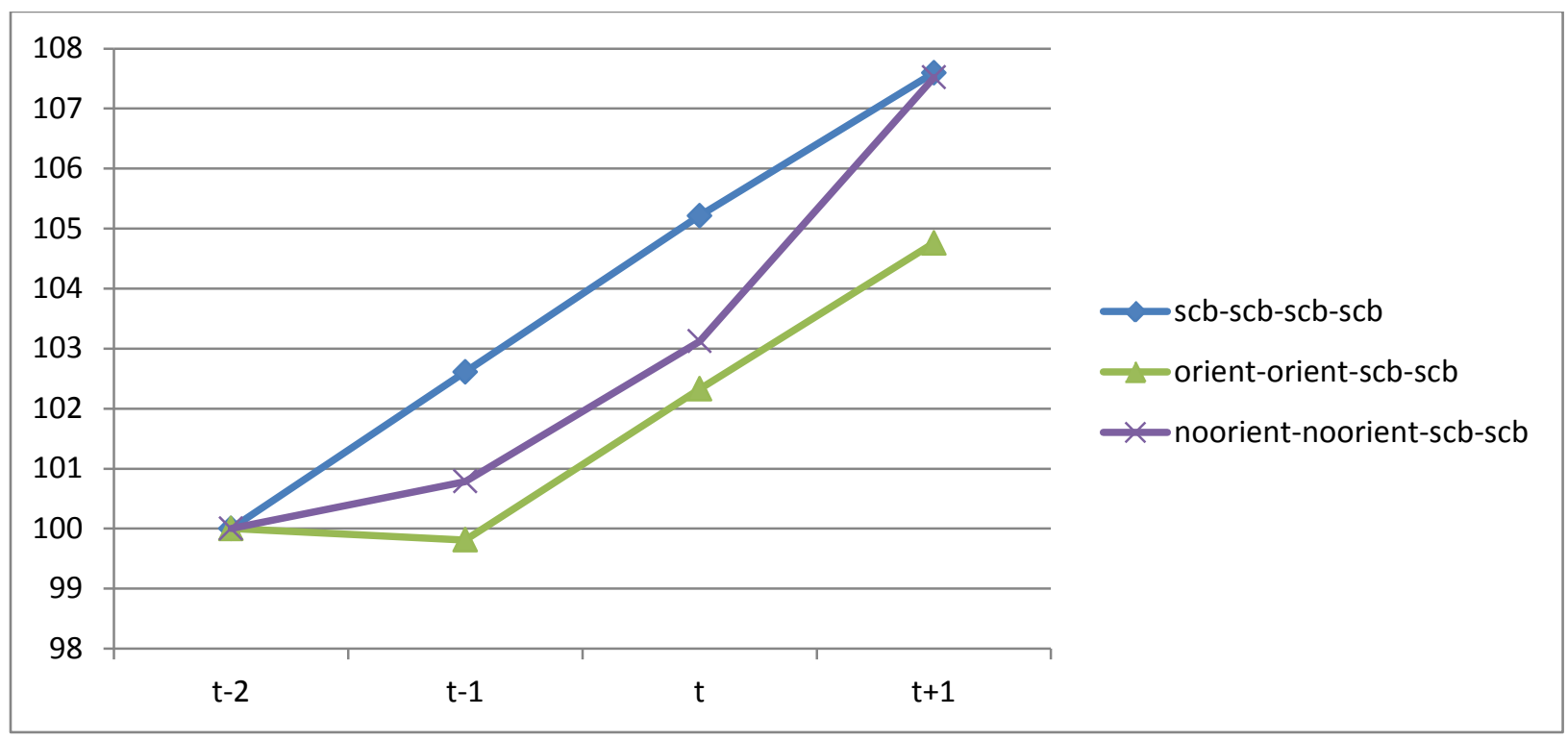

Note: See notes to Figure 3. 
Appendix: Sample Industries and Their 2-Digit Components, Before and After the SIC Changes of 2009

\begin{tabular}{|c|c|c|}
\hline \multirow[b]{2}{*}{ Industry } & \multicolumn{2}{|c|}{ 2-digit industry classification } \\
\hline & $2000-2008$ & $2009-2010$ \\
\hline Manufacturing & $\begin{array}{l}\text { Manufacture of food products } \\
\text { Manufacture of textiles and clothing, tanning and dressing of leather } \\
\text { Manufacture of paper products, printing, publishing } \\
\text { Manufacture of wood products } \\
\text { Manufacture of chemicals, coke, refined petroleum products and } \\
\text { nuclear fuel } \\
\text { Manufacture of rubber and plastic products } \\
\text { Manufacture of other non-metallic mineral products } \\
\text { Manufacture of basic metals } \\
\text { Recycling } \\
\text { Manufacture of fabricated metal products and structural metal } \\
\text { products } \\
\text { Manufacture of machinery and equipment } \\
\text { Manufacture of motor vehicles, trailers and semi-trailers } \\
\text { Manufacture of other transport equipment } \\
\text { Manufacture of electrical equipment, office machinery and } \\
\text { computers } \\
\text { Manufacture of precision and optical equipment } \\
\text { Manufacture of furniture, jewellery, musical instruments, sports } \\
\text { goods, games and toys and other products }\end{array}$ & $\begin{array}{l}\text { Manufacture of food products } \\
\text { Manufacture of textiles and clothing, tanning and dressing of leather } \\
\text { Manufacture of wood products paper, print products } \\
\text { Manufacture of chemicals, coke, refined petroleum products and nuclear fuel } \\
\text { Manufacture of rubber and plastic products } \\
\text { Manufacture of other non-metallic mineral products } \\
\text { Manufacture of basic metals } \\
\text { Manufacture of fabricated metal products (not including machinery and } \\
\text { equipment) and structural metal products } \\
\text { Manufacture of electrical equipment, office machinery and computers } \\
\text { Manufacture of precision and optical equipment } \\
\text { Manufacture of machinery and equipment } \\
\text { Manufacture of motor vehicles, trailers and semi-trailers } \\
\text { Manufacture of furniture, jewellery, musical instruments, sports goods, games and } \\
\text { toys and other products } \\
\text { Reparation of machinery installation equipment }\end{array}$ \\
\hline Construction & $\begin{array}{l}\text { Building of complete constructions or parts } \\
\text { Building installation and building completion }\end{array}$ & $\begin{array}{l}\text { Building construction and civil engineering } \\
\text { Building installation and building completion }\end{array}$ \\
\hline $\begin{array}{l}\text { Trade, Transport, } \\
\text { and Finance }\end{array}$ & $\begin{array}{l}\text { Sales, maintenance and repair of motor vehicles and motorcycles; } \\
\text { retail service of automotive fuel } \\
\text { Wholesale and commission trade } \\
\text { Retail trade, repair of personal and household goods } \\
\text { Transport } \\
\text { Communication } \\
\text { Central Banking } \\
\text { Insurance and pension funding }\end{array}$ & $\begin{array}{l}\text { Sales, maintenance and repair of motor vehicles } \\
\text { Wholesale and commission trade } \\
\text { Retail Trade, petrol stations } \\
\text { Transport and Warehousing car parks, railway stations, additional carriage, postal-, } \\
\text { courier-, express mail service } \\
\text { Information, Communication publishing, film production, rental, distribution, } \\
\text { broadcasting service, telecommunication in }\end{array}$ \\
\hline $\begin{array}{l}\text { Business } \\
\text { Services/Industry } \\
\text { Services }\end{array}$ & $\begin{array}{l}\text { Computer and related activities } \\
\text { Research and development } \\
\text { Legal, accounting, book-keeping and auditing activities, advertising, } \\
\text { market research } \\
\text { Real estate activities } \\
\text { Renting and business activities }\end{array}$ & $\begin{array}{l}\text { Real estate activities } \\
\text { Legal and tax advice, accounting } \\
\text { Administration, leadership of establishments, consulting } \\
\text { Architecture and engineering offices, technical, physical, chemical support } \\
\text { Research and development } \\
\text { Marketing and market research, design, photography, translation } \\
\text { Veterinary industry } \\
\text { Renting and business activities } \\
\text { Placement and temporary provision of labor }\end{array}$ \\
\hline
\end{tabular}




\begin{tabular}{|l|l|l|} 
& & Hawking, security agencies, landscaping, other economic services \\
\hline Other Services & Hotel and restaurants & Hotel Business and Gastronomy \\
& Education & Financial and Insurance services Industrial services \\
& Human help, veterinary and social work activities & Human Health \\
& Sewage and refusal disposal, sanitation and similar activities & Recreational, cultural and sporting activities \\
& Recreational, cultural and sporting activities & Other services (laundry/hairdressing) \\
& & \\
\hline
\end{tabular}

